\title{
SHELF LIFE OF PEACHES TREATED WITH 1-METHYLCYCLOPROPENE
}

\author{
Ricardo Alfredo Kluge ${ }^{1,3 *}$; Angelo Pedro Jacomino ${ }^{2,3}$ \\ ${ }^{1}$ Depto. de Ciências Biológicas - USP/ESALQ, C.P. 9 - CEP: 13418-900 - Piracicaba, SP. \\ ${ }^{2}$ Depto. de Produção Vegetal - USP/ESALQ. \\ ${ }^{3} \mathrm{CNPq}$ Fellow. \\ *Corresponding author <rakluge@esalq.usp.br>
}

\begin{abstract}
Peaches [Prunus persica (L.) Bastch] present reduced post-harvest shelf life, partially, due to their high respiratory rate and fast ripening. These processes are related to ethylene production, as well as its action. Peaches, cv. Aurora-1, were picked at two different ripening stages (mature green and ripe) and treated with 1-methylcyclopropene (1-MCP), the ethylene's competitive antagonist, at concentrations of 0 , 100,300 and $900 \mathrm{~nL} \mathrm{~L}^{-1}$ for 12 hours at $25^{\circ} \mathrm{C}$. After treatment, the fruits were stored at room temperature $\left(25^{\circ} \mathrm{C}\right)$ for six days. Fruits treated with 1-MCP presented better firmness and less ground color loss than nontreated fruits. The 1-MCP antagonist reduced the development of fruit rot at the mature green stage, but not at the ripe one. The 1-MCP shows commercial application potential in the treatment of peaches in order to delay the ripening process and increase their shelf life.
\end{abstract}

Key words: Prunus persica, 1-MCP, ethylene, storage, firmness

\section{VIDA ÚTIL DE PÊSSEGOS TRATADOS COM 1-METILCICLOPROPENO}

\begin{abstract}
RESUMO: Pêssegos [Prunus persica (L.) Bastch] apresentam reduzida vida útil pós-colheita devido, em parte, a sua alta taxa respiratória e amadurecimento rápido. Estes processos estão relacionados com a produção e a ação do etileno. Pêssegos cv. Aurora-1 foram colhidos em dois estádios de maturação (verde e maduro) e tratados com o antagonista competitivo do etileno 1-metilciclopropeno (1-MCP) nas concentrações de $0,100,300$ e $900 \mathrm{~nL} \mathrm{~L}^{-1}$, durante 12 horas a $25^{\circ} \mathrm{C}$. Após o tratamentos os frutos foram armazenados em condições ambientais $\left(25^{\circ} \mathrm{C}\right)$ durante seis dias. Os frutos tratados com 1-MCP apresentaram maior firmeza de polpa e menor perda de coloração de fundo se comparado com os frutos não tratados. O 1-MCP reduziu o desenvolvimento de podridões em frutos do estádio verde, mas não em frutos maduros. O 1-MCP apresenta potencial de aplicação comercial em pêssegos, visando retardar o amadurecimento e aumentar sua vida útil de prateleira.
\end{abstract}

Palavras-chave: Prunus persica, 1-MCP, etileno, armazenamento, firmeza

\section{INTRODUCTION}

Peaches have short shelf life under room temperature, partially due to their high respiratory rate and fast ripening process. Loss of pulp firmness and rot development are the main factors that lower the quality of post-harvest fruits. Therefore, these fruits are generally commercialized shortly after being harvested (Kluge et al., 1997).

Peaches are climacteric fruits and the ethylene action regulates their ripening process. At a certain stage of the ripening process, the ethylene links itself to its action site in the cell, promoting a succession of events that result in ripeness and senescence (Burg \& Burg, 1967; Lelièvre et al, 1997a).

Several compounds have shown to block the ethylene's linking site, thus inhibiting its effects (Sisler et al., 1990; Sisler, 1991). Both 2,5-norbornadiene and diazocyclopentadiene, as ethylene linkage inhibitors, can delay the softening and ripening in apples (Blankenship \& Sisler, 1989 and 1993; Gong \& Tian, 1998). However, these compounds have not been commercially accepted due to their toxicity (Fan et al., 1999).
The 1-methylcyclopropene (1-MCP) has shown to be a powerful blocking agent of the ethylene action and a ripening inhibitor. Acting as an opponent, it links itself to the ethylene's linking site. It has been verified that the 1-MCP increases conservation and shelf life of several climacteric fruits (Lelièvre et al., 1997b; Nakatsuka et al., 1997; Sisler \& Serek, 1997; Golding et al., 1998; Fan et al., 1999; Jiang et al., 1999; Abdi et al., 1998; Feng et al., 2000; Fan et al., 2000). This compound has been manufactured in powder form, releasing the 1-MCP when diluted in water or base.

The present work aimed at verifying the effect of 1-MCP on the self life of peaches stored at room temperature.

\section{MATERIAL AND METHODS}

This experiment was carried out in Piracicaba, SP, Brazil. Peaches 'Aurora 1' were picked in the Paranapanema region, SP. The harvest was carried out on the $23^{\text {rd }}$ October, 2000 and the fruits were treated the same day. Faultless peaches presenting $90 \mathrm{~g}$ average mass $( \pm 10 \mathrm{~g})$ were selected. Two ripening stages were 
employed in this study, based on the ground color of the fruit skin: a) mature green: fruits showing intense green ground coloration and b) ripe: fruits showing green ground color alteration.

Fruits were treated with Ethylbloc ${ }^{\mathrm{TM}}$, powder form, containing $0.14 \%$ active ingredient. The following concentrations were employed: 0, 100, 300 and 900 $\mathrm{nL} \mathrm{L^{-1 }}$. The application of the product was performed by placing the fruits into small hermetic chambers $\left(1.86 \mathrm{~m}^{3}\right.$ capacity) and exposing them to the gas for 12 hours at $25^{\circ} \mathrm{C}$. In order to produce the necessary 1-MCP concentrations inside the chambers, Ethylbloc ${ }^{\mathrm{TM}}$ was put inside sealed flasks $\left(0.16 \mathrm{~g}\right.$ Ethylbloc ${ }^{\mathrm{TM}}$ represents $100 \mathrm{~nL}$ of 1 -MCP in $1 \mathrm{~m}^{3}$ ). Twenty milliliters of water at $50^{\circ} \mathrm{C}$ were added to the flasks, that were then stirred until complete dissolution. Next, the flasks were opened inside the chambers, which were immediately closed so as to avoid gas loss. After a 12-hour treatment, chambers were opened and the fruits were stored at room temperature $\left(25^{\circ} \mathrm{C}\right)$.

A completely randomized factorial design was used for each ripening stage, with four replicates of 10 fruits per plot. Fruits were evaluated every two days, for 6 days at room temperature.

Firmness was measured at opposite sides of each fruit, which had a small portion of its skin removed. To perform this task, a $6 \mathrm{~mm}$-diameter needle penetrometer was used and the results were given in Newtons (N). The ground color was determined by means of a colorimeter, Minolta CR-300, and the results expressed in hue angle $\left(\mathrm{h}^{\circ}\right)$ and chroma $\left(\mathrm{C}^{*}\right)$. Rot percentage was calculated, considering the number of fruits affected within each replicate.

Data were submitted to analysis of variance and regression for the $1-\mathrm{MCP}$ concentrations using the statistical software SANEST (Zonta \& Machado, 1986).

\section{RESULTS AND DISCUSSION}

After 4 and 6 days at $25^{\circ} \mathrm{C}$, the mature green fruits treated with 1-MCP presented better firmness than the control fruits (Table 1). Firmness was 40 to $60 \%$ greater than the one observed in non-treated fruits. At this ripening stage, a $100 \mathrm{~nL} \mathrm{~L}^{-1}$ concentration showed to be enough to keep fruit firmness, considering the observed results and the quadratic behavior. Ripe fruits treated with 1-MCP showed a similar behavior in relation to the mature green fruits, however, due to the linear regression significance, it may be inferred that concentrations above $900 \mathrm{~nL} \mathrm{~L}^{-1}$ promote the maintenance of greater firmness.

Lelièvre et al. (1997a) consider that fruit softening is one of the processes most affected by ethylene. Firmness is determined by the cohesion force among pectins. As the ripening process progresses, the action of pectic enzymes takes place, turning insoluble pectin into soluble, thus promoting the softening of fruit tissues.
The greater figures of firmness verified for fruits treated with 1-MCP are probably due to a reduction in the action of ethylene. Similar results were obtained with apples (Fan et al., 1999), bananas (Jiang et al., 1999) and apricots (Fan et al., 2000).

Significant interference of 1-MCP in the ground color of fruits after 2 and 4 days at $25^{\circ} \mathrm{C}$ (Tables 2 and 3 ) was verified. There was a quadratic behavior within the periods evaluated, indicating that greater product concentrations do not seem to promote better results in relation to the maintenance of the color. Fruits treated with 1-MCP showed higher hue angle (greener) when compared to control fruits and lower chroma (more intense green). The loss of green color is due to the rupture of chlorophyll molecules, the chlorophyllase enzyme being involved in this process. The increase in the activity of such enzyme seems to be associated to the ethylene action during the ripening process (Tucker, 1993). Once the ethylene action is blocked by 1-MCP, a decrease in the chlorophyllase activity may be possible.

The treatment with $1-\mathrm{MCP}$ reduced the percentage of mature green fruits affected by rot, but showed no effect on ripe fruits (Table 4). A concentration of $100 \mathrm{~nL} \mathrm{~L}^{-1} 1$-MCP seems to be adequate to slow down rot development in mature green fruits, considering the results observed and the quadratic behavior. The main fungus that affected the fruits was Monilinia (found in more than $90 \%$ of the affected fruits). In peaches, rot development increases as the ripening process takes places, being one of the main problems that decrease the fruit post-harvest quality (Kluge et al., 1997). Considering this aspect, 1-MCP seems to indirectly affect the growth of fungi responsible for rot

Table 1 - Effect of 1-MCP on firmness for peaches picked at two different ripening stages and stored at $25^{\circ} \mathrm{C}$.

\begin{tabular}{|c|c|c|c|c|}
\hline \multirow{2}{*}{ 1-MCP $\left(n L L^{-1}\right)$} & \multicolumn{4}{|c|}{ Days at $25^{\circ} \mathrm{C}$} \\
\hline & 0 & 2 & 4 & 6 \\
\hline \multicolumn{5}{|c|}{ Mature green Stage } \\
\hline & ------- & -- fimn & $(\mathrm{N})$ & ------ \\
\hline 0 & 16.75 & 12.23 & 7.48 & 5.77 \\
\hline 100 & 16.75 & 14.91 & 10.66 & 7.12 \\
\hline 300 & 16.75 & 13.66 & 11.37 & 7.07 \\
\hline 900 & 16.75 & 14.06 & 10.66 & 7.92 \\
\hline L & & NS & NS & NS \\
\hline Q & & * & $* *$ & $* *$ \\
\hline
\end{tabular}

\begin{tabular}{lcccc}
\hline \multicolumn{5}{c}{ Ripe Stage } \\
& ------ & & \\
0 & 12.18 & 5.73 & 3.94 & 3.76 \\
100 & 12.18 & 10.03 & 5.92 & 4.07 \\
300 & 12.18 & 9.09 & 6.63 & 4.97 \\
900 & 12.18 & 8.82 & 8.33 & 5.37 \\
\hline $\mathrm{L}$ & & $\mathrm{NS}$ & $*$ & $*$ \\
$\mathrm{Q}$ & & $* *$ & $*$ & $*$ \\
\hline
\end{tabular}

L, Q, NS, ${ }^{*},{ }^{* *}=$ Linear behavior, quadratic behavior, non-significant and significant at $\mathrm{P} \leq 0.05$ or $\mathrm{P} \leq 0.01$, respectively. 
Table 2 - Effect of 1-MCP on hue angle for peaches picked at two different ripening stages and stored at $25^{\circ} \mathrm{C}$.

\begin{tabular}{|c|c|c|c|c|}
\hline \multirow{2}{*}{ 1-MCP $\left(n L L^{-1}\right)$} & \multicolumn{4}{|c|}{ Days at $25^{\circ} \mathrm{C}$} \\
\hline & 0 & 2 & 4 & 6 \\
\hline \multicolumn{5}{|c|}{ Mature green Stage } \\
\hline & \multicolumn{4}{|c|}{---- hue angle $\left(h^{\circ}\right)$} \\
\hline 0 & 98.09 & 88.07 & 79.82 & 75.42 \\
\hline 100 & 98.09 & 89.45 & 82.71 & 76.38 \\
\hline 300 & 98.09 & 84.17 & 83.45 & 76.22 \\
\hline 900 & 98.09 & 87.14 & 83.69 & 77.67 \\
\hline $\mathrm{L}$ & & NS & NS & NS \\
\hline Q & & * & * & NS \\
\hline
\end{tabular}

\begin{tabular}{lcccc}
\hline \multicolumn{5}{c}{ Ripe Stage } \\
& $---1-$ & & \\
0 & 81.65 & 70.12 & 67.80 & 67.63 \\
100 & 81.65 & 71.04 & 75.22 & 65.75 \\
300 & 81.65 & 75.07 & 74.60 & 69.37 \\
900 & 81.65 & 79.04 & 73.55 & 68.69 \\
\hline L & & $*$ & NS & NS \\
Q & & $*$ & $*$ & NS \\
\hline
\end{tabular}

$\mathrm{L}, \mathrm{Q}, \mathrm{NS},{ }^{*}=$ Linear behavior, quadratic behavior, non-significant and significant at $\mathrm{P} \leq 0.05$, respectively.

Table 3 - Effect of 1-MCP on chroma for peaches picked at two different ripening stages and stored at $25^{\circ} \mathrm{C}$.

\begin{tabular}{|c|c|c|c|c|}
\hline \multirow{2}{*}{ 1-MCP $\left(n L L^{-1}\right)$} & \multicolumn{4}{|c|}{ Days at $25^{\circ} \mathrm{C}$} \\
\hline & 0 & 2 & 4 & \\
\hline \multicolumn{5}{|c|}{ Mature green Stage } \\
\hline & ------- & ---- chr & a ------ & ------ \\
\hline 0 & 45.73 & 46.85 & 52.21 & 54.79 \\
\hline 100 & 45.73 & 46.80 & 52.21 & 56.40 \\
\hline 300 & 45.73 & 45.45 & 51.24 & 55.77 \\
\hline 900 & 45.73 & 45.90 & 46.03 & 52.51 \\
\hline L & & NS & NS & NS \\
\hline Q & & NS & * & NS \\
\hline
\end{tabular}

Ripe Stage

\begin{tabular}{lrrrc} 
& & & & \\
0 & 46.23 & 47.51 & 52.10 & 51.58 \\
100 & 46.23 & 48.54 & 52.30 & 49.89 \\
300 & 46.23 & 47.88 & 51.51 & 51.95 \\
900 & 46.23 & 46.41 & 47.99 & 49.89 \\
\hline L & & NS & NS & NS \\
Q & & NS & $*$ & NS \\
\hline
\end{tabular}

L, Q, NS, * = Linear behavior, quadratic behavior, non-significant and significant at $P \leq 0.05$, respectively.

development in mature green fruits, due to delaying the loss of firmness. Concerning the ripening stage, there were no significant differences among treatments, despite rot percentage being higher than the one observed for mature green fruits. At this more advanced ripening stage, 1-MCP was unable to reduce rot development.
Table 4 - Effect of 1-MCP on rot percentage for peaches picked at two different ripening stages and stored at $25^{\circ} \mathrm{C}$

\begin{tabular}{|c|c|c|c|c|}
\hline \multirow{2}{*}{ 1-MCP $\left(n L L^{-1}\right)$} & \multicolumn{4}{|c|}{ Days at $25^{\circ} \mathrm{C}$} \\
\hline & 0 & 2 & 4 & 6 \\
\hline \multicolumn{5}{|c|}{ Mature green Stage } \\
\hline & ------- & ---- ro & ) ------ & ----- \\
\hline 0 & 0.00 & 14.16 & 14.16 & 14.78 \\
\hline 100 & 0.00 & 5.00 & 5.62 & 5.62 \\
\hline 300 & 0.00 & 5.00 & 5.62 & 5.62 \\
\hline 900 & 0.00 & 2.50 & 2.50 & 2.50 \\
\hline $\mathrm{L}$ & & NS & NS & NS \\
\hline$Q$ & & ** & ** & ** \\
\hline
\end{tabular}

\begin{tabular}{lrrrr}
\hline \multicolumn{5}{c}{ Ripe Stage } \\
& & \\
\hline 0 & 0.00 & 11.67 & 21.92 & 36.67 \\
100 & 0.00 & 10.30 & 26.25 & 30.62 \\
300 & 0.00 & 10.30 & 24.00 & 25.00 \\
900 & 0.00 & 10.64 & 20.31 & 33.95 \\
\hline $\mathrm{L}$ & & $\mathrm{NS}$ & $\mathrm{NS}$ & $\mathrm{NS}$ \\
$\mathrm{Q}$ & & $\mathrm{NS}$ & $\mathrm{NS}$ & $\mathrm{NS}$ \\
\hline
\end{tabular}

$\mathrm{L}, \mathrm{Q}, \mathrm{NS},{ }^{* *}=$ Linear behavior, quadratic behavior, non-significant and significant at $P \leq 0.01$, respectively.

The use of 1-MCP can effectively lengthen the shelf life of peaches stored at room temperature, once it reduces loss of firmness, as well as color alterations, both processes related to fruit ripening. A longer shelf life is important when considering the high perishability of non-refrigerated fruits. Besides, longer shelf life may enable the transportation of such fruits through longer distances. Therefore, it has been confirmed that 1-MCP presents potential use for ripening control and increase of shelf life of peaches. However, the best product concentration is still under study, as it has been verified, through chromatography, that the 1-MCP concentration inside the experimental chamber is not constant. Consequently, it is necessary to check the levels of this ethylene inhibitor in the environment where the application is to be performed, in order to identify the best concentrations for each kind of fruit and cultivar.

\section{REFERENCES}

ABDI, N.; McGLASSON, W.B.; HOLFORD, P.; WILLIAMS, M.; MIZRAHI, Y. Responses of climacteric and suppressedclimacteric plums to treatment with propylene and 1methylcyclopropene. Postharvest Biology and Technology, v.14, p.29-39, 1998.

BLANKENSHIP, S.M.; SISLER, E.C. 2,5-norbornadiene retards apple softening. HortScience, v.24, p.313-314, 1989.

BLANKENSHIP, S.M.; SISLER, E.C. Response of apples to diazocyclopentadiene inhibition of ethylene binding. Postharvest Biology and Technology, v.3, p.95-101, 1993.

BURG, S.P.; BURG, E.A. Molecular requirements for the biological activity of ethylene. Plant Physiology, v.42, p.144152, 1967. 
FAN, X.; ARGENTA, L.; MATTHEIS, J.P. Inhibition of ethylene action by 1-methylcyclopropene prolongs storage life of apricots. Portharvest Biology and Technology, v.20, p.135142, 2000.

FAN, X.; BLANKENSHIP, S.M.; MATTHEIS, J.P. 1methylcyclopropene inhibits apple ripening. Journal of the American Society for Horticultural Science, v.124, p.690695, 1999.

FENG, X.; APELBAUM, A.; SISLER, E.C.; GOREN, R. Control of ethylene responses in avocado fruit with 1methylcyclopropene. Portharvest Biology and Technology, v.20, p.143-150, 2000.

GOLDING, J.B.; SHEARER, D.; WYLLIE, S.G.; McGLASSON, W.B. Application of 1-MCP and propylene to identify ethylenedependent ripening processes in mature banana fruit. Portharvest Biology and Technology, v.14, p.87-98, 1998.

GONG, Y.; TIAN, M.S. Inhibitory effect of diazocyclopentadiene on the development of superficial scald in 'Granny Smith' apples. Plant Growth Regulation, v.26, p.117-121, 1998.

JIANG, Y.; JOYCE, D.C.; MACNISH, A.J. Extension of the shelf life of banana fruit by 1-methylcyclopropene in combination with polyethylene bags. Postharvest Biology and Technology, v.16, p.187-193, 1999.

KLUGE, R.A.; NACHTIGAL, J.C.; FACHINELLO, J.C.; BILHALVA, A.B. Fisiologia e manejo pós-colheita de frutas de clima temperado. Pelotas: Ed. UFPel, 1997. 163p.

LELIĖVRE, J.M.; LATCHÉ, A.; JONES, B.; BOUZAYEN, M.; $\mathrm{PECH}$, J.C. Ethylene and fruit ripening. Physiologia Plantarum, v.101, p.727-739, 1997a.
LELIĖVRE, J.M.; TICHIT, L.; DAO, P.; FILLION, L.; NAM, Y.W.; PECH, J.C.; LATCHÉ, A. Effects of chilling on the expression of ethylene biosynthetic genes in Passe-Crassane pear (Pyrus communis L.) fruits. Plant Molecular Biology, v.33, p.847855, $1997 b$.

NAKATSUKA, A.; SHIOMI, S.; KUBO, Y.; INABA, A. Expression and internal feedback regulation of ACC synthase and ACC oxidase genes in ripening tomato fruit. Plant and Cell Physiology, v.38, p.1130-1110, 1997.

SISLER, E.C. Ethylene binding components in plants. In: MATTOO, A.K.; SUTTLE, J.C. (Ed.) The plant hormone ethylene. Boca Raton: CRC Press, 1991. p.81-99.

SISLER, E.C.; BLANKENSHIP, S.M.; GUEST, M. Competition of cyclooctenes and cyclooctadienes for ethylene binding and activity in plants. Plant Growth Regulation, v.9, p.157-164, 1990.

SISLER, E.C.; SEREK, M. Inhibitors of ethylene responses in plants at the receptors level: recent developments. Physiologia Plantarum, v.100, p.577-582, 1997.

TUCKER, G.A. Introduction. In: SEYMOUR, G.B.; TAYLOR, J.E.; TUCKER, G.A. (Ed.) Biochemistry of fruit ripening. London: Chapman \& Hall, 1993. p.1-51

ZONTA, E.P.; MACHADO, A.A. Sistema de Análise Estatística ara microcomputadores - "SANEST" (software). Pelotas: UPFEL, Instituto de Física e Matemática, 1986.

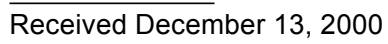

